\title{
MATERNAL AND FETAL OUTCOMES OF PREGNANCIES TREATED FOR H1N1 VIRUS INFECTION
}

\author{
Bilge Cetinkaya DEMIR, Ayse Topcu AKDUMAN, Nefise Tanridan OKCU, Yalcin KIMYA
}

Department of Obstetrics and Gynecology, Uludag University, Faculty of Medicine, Bursa, Turkey

\begin{abstract}
SUMMARY
Aim: At the time of the outbreak of influenza A H1N1, mostly known as swine flu, first case in Turkey was diagnosed in May 2009. The period from June 2009 to August 2010 was declared to be pandemy H1N1 by World Health Organization (WHO). In this study we aimed to assess the maternal and fetal outcomes of pregnant women with the diagnosis of H1N1viral infection, who were hospitalized during 2009 pandemy.

Materials and methods: The clinical data, treatment modalities and maternal and fetal outcomes of 9 pregnant women with H1N1 infection were retrieved from patients file and evaluated retrospectively. Patients were classified as confirmed case if the nasopharyngeal swabs were pozitive with real time PCR (rRT-PCR) and suspected case if rRTPCR was negative.

Findings: At admission one patient was in first trimester, 2 were in second trimester and other 6 patients were in third trimester. The presenting symptoms were cough (77\%), fever (77\%), sore throat (11\%), dyspnea/respiratory distress (44\%) and malaise (22\%). All of the patients were treated with oseltamivir and with appropriate antibiotics in case of secondary bacterial pneumonia. Median hospitalisation time was 23 days (7-40). Five patients required mechanical ventilatory support. One of the patients and 2 of the neonates passed away.

Conclusion: Although swine flu causes mild to moderate flu like symptoms in most of the population, in pregnant women it may lead to lethal complications. Thus the appropriate antiviral treatment should begin immediately within 48 hours.
\end{abstract}

Key words: H1N1 infection, newborn, pregnancy

Journal of Turkish Society of Obstetrics and Gynecology, (J Turk Soc Obstet Gynecol), 2013; Vol: 10, Issue: 4, Pages: 220- 5

\section{H1N1 ENFEKSIYONU NEDENIYLE TEDAVI EDILEN GEBELERIN MATERNAL VE FETAL SONUÇLARI}

\section{ÖZET}

Amaç: Influenza A H1N1, daha sık bilinen adıyla domuz gribi, Türkiye'de ilk olarak Mayıs 2009'da görüldü. Haziran 2009 ile Ağustos 2010 tarihleri arası Dünya Să̆lık Örgütü tarafindan H1N1 pandemisi olarak kabul edildi. Bu çalışmada, 2009 pandemisinde hastanemizde yatarak tedavi alan H1N1 viral enfeksiyonu olan gebelerin ve yenidoğan bebeklerin değerlendirilmesi amaçlanmıştır.

Gereç ve yöntemler: Pandemi esnasında hastanemizde yatarak tedavi alan 9 ciddi H1N1 tanıl gebenin klinik seyirleri, tedavi yöntemleri, maternal ve fetal sonuçları izlemleri esnasında kayıt altına alındıktan sonra veriler retrospektif olarak değerlendirilmeye tabii tutuldu. Nazofarengeal sürüntülerinde, H1N1 virusü real-time PCR (rRT-PCR) ile teyit edilen gebeler kesin olgu, teyit edilemeyenler ise olası olgu olarak kabul edildi.

Address for Correspondence: Dr. Bilge Çetinkaya Demir. Uludağ Üniversitesi Tıp Fakültesi, Kadın Hastalıkları ve Doğum Anabilim Dalı, 16059, Bursa Phone: +90(505) 5827972

e-mail: bilgecd@uludag.edu.tr

Received: 27 July 2013, revised: 06 August 2013, accepted: 07 August 2013, online publication:13 August 2013 
Bulgular: Başvuru sırasında bir hasta birinci trimesterde, iki hasta 2. trimesterde ve 6 hasta 3. trimesterde idi. Başvuru semptomları öksürük (\%77), ateş yüksekliği (\%77), boğaz ağrısı (\%11), nefes darlı̆̆ı/solunum sıkıntısı (\%44) ve halsizlik (\%22) idi. Olguların tümü oseltamivir tedavisi ald, ĕger sekonder pnömoni tablosu mevcut ise ek antibiyotik tedavisi başlandl. Olguların medyan hastanede kalış süreleri 23 gün (7-40 gün) idi. Beş hasta reanimasyon kliniğinde mekanik ventilatör desteğine ihtiyaç duydu. Bir anne kaybedildi, iki bebek ise neonatal dönemde yaşamını yitirdi. Sonuç: Domuz gribi gebelerde hayatı tehdit edici komplikasyonlara neden olabilmektedir. Yoğun bakım ihtiyacı gebe bir olguda artmaktadır. Gebelerin ayırıcı tanının yapılmasının ardından antiviral tedavisine şikayetlerden sonraki ilk 48 saatte başlanması önerilir.

Anahtar kelimeler: gebelik, H1N1 enfeksiyonu, yenidoğan

Türk Jinekoloji ve Obstetrik Derneği Dergisi, (J Turk Soc Obstet Gynecol), 2013; Cilt: 10, Sayl: 4, Sayfa: 220- 5

\section{INTRODUCTION}

The main cause of seasonal flu is Influenza virus, a member of Orthomyxovirus family. Two genera of this RNA virus family, Influenza A and B, cause epidemics in human. Influenza A viruses are further classified, based on the viral surface proteins hemagglutinin (HA or $\mathrm{H}$ ) and neuraminidase (NA or N) such as H1N1, H5N1. Their ability of reassortment and genetic shifting causes new pandemics worldwide. Swine flu is a novel strain of the influenza A virus affecting humans and contains segments of genes from pig, bird and human influenza viruses ${ }^{(1)}$.

Swine flu caused the first outbreak in Mexico in April 2009. The first case in Turkey was reported in May 2009(2). The outbreak was declared a global pandemic by the World Health Organisation (WHO) from 11 June 2009 until 10 August 2010(1).

Pregnant women were severely affected during pandemy and classified in high risk group for swine $\mathrm{flu}^{(3,4)}$. Preventive strategies and appropriate treatment modalities for pregnant women were among the major concerns for health services during pandemy. In high risk groups including pregnant women comprehensive treatment methods were required ${ }^{(5)}$.

In this retrospective study we aimed to asses the obstetric outcomes in pregnant women who were hospitalized with the diagnosis of H1N1 viral infection during 2009 pandemy.

\section{MATERIALS AND METHODS}

The pregnant women who admitted to obstetrics clinics, emergency services and infectious disease clinics of a tertiary university hospital with symptoms of flu between November 2009 and March 2010 were evaluated. Those who had the diagnosis of swine flu and hospitalised were enrolled in the study. In the diagnosis of H1N1 influenza viral infection we used the diagnostic criteria set by Turkish Ministery of Health, Pandemy Coordination Group ${ }^{(6)}$. The patients with at least one of the foolowing symptoms or signs were defined as severe H1N1 infection; persistant fever $\left(>38^{\circ} \mathrm{C}\right)$ for at least 3 days, nausea, vomitting, diarrhea, dehydration, chest pain and productive coughing, dyspnea, lethargy, pneumonia, acute respiratory distress syndrome (ARDS), multiple organ failure and need for mechanical ventilation. The patients with only clinical H1N1 influenza infection symptoms were defined as "suspected case". If the clinical infection was confirmed with nasopharyngeal specimens by realtime reverse-transcriptase polymerase chain reaction (rRT-PCR), then the patient was defined as "confirmed case".

During the hospitalization period fetal well being was evaluated by cardiotocogram, ultrasonography and biophysical profile. This study was approved by the ethical committee of Uludag University.

\section{RESULTS}

During 2009 swine flu pandemy 9 pregnant women were hospitalized with the diagnosis of severe H1N1 influenza infection. Median age of the patients were 29 years (22-36). At admission among these patients, one was in first trimester, 2 were in second and 6 were in third trimester. One patient had the risk factors for acute respiratory distress syndrome (ARDS) such as hypertension, psoriasis and obesity. The most common presenting symptoms were cough (77\%), fever (77\%), 
sore throat (11\%), dyspnea(44\%) and fatigue (22\%). Three patients were admitted to hospital five days after the symptoms started. The nasopharyngeal samples for H1N1 rRT- PCR could not be collected in these 3 patients. Five patients were positive for H1N1 rRTPCR and accepted as confirmed cases.

All patients were treated with oseltamavir $(75 \mathrm{mg}$ p.o. $2 \times 1)$. Six patients had secondary bacterial pneumonia and were treated with appropriate antibiotics or antifungal drugs (Meropenem, Vancomycin, Flucanozole). Five patients were intubated and treated in intensive care unit (ICU) with the diagnosis of ARDS. The duration of stay in ICU were 5 to 35 days (Table II). Patients spent a median of 23 days in hospital (7-40 days).
Four patients delivered after treatment was completed however others delivered while treatment was ongoing. Three patients who were treated in ICU were delivered with emergency bedside cesarean section inside the unit due to maternal deterioration in hypoxemia and acute fetal distress. Four pregnant women delivered before 35 weeks of pregnancy. Three of them were the ones treated in ICU. The median week of delivery of patients in ICU was 34 weeks (29-39 wks) with a median birth weight of 2040 gr. Patients who did not need ICU, delivered at 37 weeks (35-39 wks) with a median birth weight of $3025 \mathrm{gr}$ (Table I, Table II). No fetal demise was detected. One patient died after cesarean section due to ARDS and multiple organ failure. This patient admitted to hospital seven days

Table I: Maternal and fetal outcomes of pregnant women.

\begin{tabular}{|c|c|c|c|c|c|c|c|c|c|c|c|c|}
\hline Case & Age & $\begin{array}{l}\text { Gest } \\
\text { week at } \\
\text { diagnosis }\end{array}$ & $\begin{array}{l}\text { Suspected } \\
\text { confirmer }\end{array}$ & $\begin{array}{l}\text { ed Symptoms } \\
\text { ed }\end{array}$ & $\begin{array}{l}\text { Pnuemonia/ } \\
\text { ARDS }\end{array}$ & $\begin{array}{l}\text { Admisson } \\
\text { to } \\
\text { ICU }\end{array}$ & $\begin{array}{l}\text { Maternal } \\
\text { outcome }\end{array}$ & $\begin{array}{l}\text { Delivery time/ } \\
\text { mode }\end{array}$ & $\begin{array}{l}\text { Total } \\
\text { Hospitalization } \\
\text { time }\end{array}$ & $\begin{array}{l}\text { APGAR } \\
\text { scores } \\
\text { At } \\
1 \text { and } 5 \\
\text { min }\end{array}$ & $\begin{array}{l}\text { Birth } \\
\text { weight } \\
\text { (gr) }\end{array}$ & $\begin{array}{l}\text { Neonatal } \\
\text { outcome }\end{array}$ \\
\hline 1 & 30 & $17 \mathrm{wk}$ & $\mathrm{S}$ & $\begin{array}{l}\text { Sore throat, } \\
\text { coughing, fever }\end{array}$ & $-1-$ & - & alive & 36. wk, VD & 8 & $8-8$ & 3600 & Alive \\
\hline 2 & 25 & $26 \mathrm{wk}$ & $\mathrm{C}$ & $\begin{array}{l}\text { Coughing, } \\
\text { respiratory distress }\end{array}$ & $+/+$ & + & Exitus & 29. wkt, emrg C/S & 25 & $2-5$ & 980 & $\begin{array}{l}\text { Exitus, } \\
\text { H1N1 }\end{array}$ \\
\hline 3 & 30 & $31 \mathrm{wk}$ & $\mathrm{C}$ & $\begin{array}{l}\text { Coughing, } \\
\text { respiratory distress }\end{array}$ & $+/+$ & + & Alive & 32. wk,emrg C/S & 40 & $1-3$ & 1590 & Exitus \\
\hline 4 & 23 & $33 \mathrm{wk}$ & $\mathrm{C}$ & $\begin{array}{l}\text { Fever, Nausea,vomitting, } \\
\text { Respiratory distress }\end{array}$ & $+/-$ & + & Alive & 34. wk, emrg C/S & 23 & $1-4$ & 2040 & Alive \\
\hline 5 & 22 & $35 \mathrm{wk}$ & $\mathrm{S}$ & $\begin{array}{l}\text { coughing, fever, } \\
\text { respiratory distress }\end{array}$ & $-1-$ & - & Alive & 35. wk, VD & 8 & $1-4$ & 2810 & Alive \\
\hline 6 & 36 & $12 \mathrm{wk}$ & $\mathrm{C}$ & Fever & $+/+$ & + & Alive & 39. wk, VD & 36 & $10-10$ & 3000 & Alive \\
\hline 7 & 28 & $37 \mathrm{wk}$ & $\mathrm{S}$ & $\begin{array}{l}\text { Coughing, sputum } \\
\text { fever,myalgia }\end{array}$ & $+/-$ & + & Alive & 37. wk, emrg C/S & 28 & $9-10$ & 3270 & Alive \\
\hline 8 & 29 & $33 \mathrm{wk}$ & $\mathrm{C}$ & $\begin{array}{l}\text { Coughing, fever } \\
\text { fatique }\end{array}$ & $+/-$ & - & Alive & 38. wk, elec C/S & 8 & $9-10$ & 2850 & Alive \\
\hline 9 & 29 & $35 \mathrm{wk}$ & $\mathrm{S}$ & $\begin{array}{l}\text { Coughing, fever } \\
\text { fatique, headache }\end{array}$ & $-/-$ & - & Alive & 39. wk, elec C/S & 8 & $10-10$ & 3200 & Alive \\
\hline
\end{tabular}

ARDS: Acute respiratory distress syndrome, VD: Vaginal delivery, C/S: cesarean section, emrg: emergency, elec: elective.

Table II: Pregnant women treated at ICU.

\begin{tabular}{|c|c|c|c|c|c|c|c|c|}
\hline Case & Age & $\begin{array}{l}\text { Delivery } \\
\text { time }\end{array}$ & $\begin{array}{l}\text { Risk } \\
\text { factors }\end{array}$ & $\begin{array}{l}\text { Time } \\
\text { interval } \\
\text { up to } \\
\text { treatment }\end{array}$ & Treatment & $\begin{array}{l}\text { Hospital } \\
\text { time } \\
\text { in } \\
\text { ICU }\end{array}$ & H1N1 rRT-PCR & Outcome \\
\hline 2 & 25 & $29 \mathrm{wk}$ & No & 7 days & $\mathrm{MV}$, multiple drug tx & 23 day & Positive & Exitus \\
\hline 3 & 30 & $32 \mathrm{wk}$ & No & 8 days & $\mathrm{MV}$, multiple drug tx & 35 day & Positive & Alive \\
\hline 4 & 23 & $34 \mathrm{wk}$ & No & 3 days & MV, multiple drug tx & 10 day & Positive & Alive \\
\hline 6 & 36 & $39 \mathrm{wk}$ & $\begin{array}{l}\text { Obesity } \\
\text { psoriazis, } \\
\text { HT }\end{array}$ & 3 days & MV, multiple drug tx & 22 day & Positive & Alive \\
\hline 7 & 28 & $37 \mathrm{wk}$ & No & 7 days & $\mathrm{MV}$, multiple drug tx & 5 day & Negative & Alive \\
\hline
\end{tabular}

HT: Hypertension, MV: Mechanical ventilation, Multiple drug tx: Oseltamavir and other appropriate drugs in ICU 
after her symptoms started and so that treatment could not be started earlier. Two preterm newborns delivered in ICU by cesarean section were treated in NICU. Both of these two preterms passed away.

\section{DISCUSSION}

Upper airway tract infections may cause a series of fetal and maternal morbidities and mortality. Type of infectious agent, week of pregnancy, concomitant diasease of pregnant women and immunologic factors influence the perinatal outcomes of the disease ${ }^{(7)}$. The 2009 H1N1 influenza pandemy caused a higher rate of mortality in children below 5 years of age and pregnant women ${ }^{(8,9)}$. Although the H1N1 influenza virus infection lasted 7 days in immunocompetent human, it was complicated with secondary viral or bacterial pneomonia in high risk groups (such as; health care professionals, patients with chronic illness, diabetics, morbid obese patients and pregnants) $(1,8,10)$.

Pregnant women can be infected with H1N1 virus in any trimester. The majority of hospitalized cases were in the third trimester in our series (66\% of cases) similar to previous series $(11,12)$. Creagna et al reported that $54.8 \%$ of severe H1N1 influenza cases were at third trimester(11). In another study among 18 hospitalized pregnant women with the diagnosis of $\mathrm{H} 1 \mathrm{~N} 1$ influenza, $67 \%$ were in the third trimester(12). Termination of first or early second trimester pregnancies was not recomended if the patient was infected with $\mathrm{H} 1 \mathrm{~N} 1$ $\operatorname{virus}^{(1)}$.

Pregnant women were reported to have 4 to 7 fold greater risk for hospitalization during 2009 H1N1 pandemy(10,11). A study from Australia and New Zeland pointed out that, $49 \%$ of H1N1 influenza virus infected pregnants were complicated by viral pneumonia or ARDS and $20 \%$ by secondary bacterial pneumonia (13). Similarly another study from USA reported that $40 \%$ of 272 hospitalized patients with a diagnosis of swine flu were complicated with secondary bacterial pneumonia $^{(12)}$. However we were not able to asses the percentage of hospitalization in pregnants since we could not retrieve all the pregnant files with the diagnosis of H1N1 influenza virus infection. The swine flu also had other complications such as myocarditis and neurologic complications. Meningitis, encephalitis and bacteremia were the causes of death in patients ${ }^{(13)}$. In a series from Turkey, among 16 pregnant women 14 were diagnosed with pneumonia and subsequently 2 died due to respiratory failure during 2009 H1N1inflenza flu pandemy(2). In another case report from Turkey, one of 2 pregnant women died due to complication of H1N1virus infection(14).

Both the need for ICU and mortality rates were increased if the patients had dyspnea, tachpnea $(>30 / \mathrm{min})$, tachycardia, pneumonia, loss of conciousness and need oxygen supply during $\operatorname{admission}^{(1)}$. Studies reported that the rate of ICU requirement among pregnant women were between 7 to $9 \%(10,13)$. We could not analyse a total rate of admission to ICU among all pregnant patients. However $55 \%$ of hospitalized pregnant women needed ICU in our series. In another study authors reported that, pregnant women with a gestation of 20 weeks or more had a 13-fold greater risk of admission to an ICU, compared to nonpregnants during $2009 \mathrm{H} 1 \mathrm{~N} 1$ influenza infection $^{(3)}$. Although $90 \%$ of pregnant patients admitted to ICU were not in first trimester, it should not be forgotten that first trimester pregnant woman with $\mathrm{H} 1 \mathrm{~N} 1$ virus infection can also need ICU treatment $(15)$.

The number of maternal deaths reported related to H1N1 virus infection during 2009 pandemy in United Kingdom and USA were 12 and 28, respectively $(1,11)$. Louie et al reported maternal death rate due to $\mathrm{H} 1 \mathrm{~N} 1$ influenza infection as 4.3/100.000 live births( ${ }^{(16)}$. In other reports the maternal death rate was reported as $4-11 \%$ for all trimesters $(3,11,15)$. Among 509 hospitalized pregnants in USA $7.6 \%$ was in first trimester and 7.1\% of maternal deaths were in first trimester during 2009 pandemy ${ }^{(15)}$. In our series one first trimester pregnancy was succesefully treated in ICU and she delivered at 35 weeks of pregnancy. Maternal mortality was common in pregnant women who are in third trimester, admitted to ICU and treated later than 2nd day of infection $^{(1,3,11,15)}$.

Today two antiviral agents are avaliable for treatment of H1N1 influenza infection. Neurominidase inhibitors (Oseltamivir and Zanamivir) are the agents mostly used. These agents are categorised as " $\mathrm{C}$ " for pregnancy by $\operatorname{FDA}^{(17)}$. Oseltamivir is used as per oral and zanamivir is used as inhaler. Although oseltamivir has been shown to cross the placenta and breast milk in small amounts, no adverse effects on the fetus or 
pregnancy have been recorded(1). Treatment should be given within 48 hours after initial symptoms, neverthless the benefits of late treatment have been shown $(11,17,18)$. Treatment with antivirals should be started on clinical suspicion whilst awaiting test results. A negative test result can not rule out the diagnosis since the sensitivity of rapid influenza diagnostic test can range from 10 to $70 \%$ for $2009 \mathrm{H} 1 \mathrm{~N} 1$ virus ${ }^{(11)}$. Postexposure prophylaxis with antivirals has been shown to be effective in prevention of infection ${ }^{(1)}$. Since prophylaxis may inhibit immunity and may predispose to development of resistance, it is only recommended for very high-risk individuals ${ }^{(17)}$. Compared to nonpregnants, pregnant women has no different adverse effect and they are recommended to be vaccinated irrespective of gestational week $(7,19,20)$

According to our study we suggested that to start treatment early in pregnants influences the prognosis and perinatal outcomes. The newborns and the patients who were treated in ICU had worse prognosis. The pregnant women with respiratory problems should be evaluated carefully and obstetric complications such as pulmonary emboli and preeclampsia, should be excluded. The appropriate treatment should be planed after detailed evaluation of the pregnant women in cooperation with obstetrician and respiratory physician, hematologist and other medical stuff. The patients who need respiratory support should be managed in ICU.

\section{CONCLUSION}

Swine flu gave rise to life threatening complications in pregnant women although it caused mild symptoms in immunocompotent patients. Thus pregnant women should admit to hospital as soon as possible to seek treatment when the symptoms of flu starts. The pregnant women especially in third trimester and with risk factors like asthma and obesity are highly vulnerable to possible complications. The antiviral treatment should be started within 48 hours. Nevertheless treatment can also be effective up to 7 days. We should recommend pregnant women to be vaccinated against influenza especially during epidemics at winter time.

\section{REFERENCES}

1. Lim BH, Mahmood TA. Influenza A H1N1 2009 (Swine Flu) and Pregnancy. J Obstet Gynaecol India. 2011 Aug;61(4): 386-93.

2. Soydinc HE, Celen MK, Yıldız B, Sak ME, Evsen MS, Gul T. Pregnancy and H1N1 infection in Southeast Turkey. J Infect Dev Ctries. 2012 Aug;6(8):644- 9.

3. The ANZIC Influenza Investigators and Australasian Maternity Outcomes Surveillance System. Critical illness due to 2009 $\mathrm{A} / \mathrm{H} 1 \mathrm{~N} 1$ influenza in pregnant and postpartum women: population based cohort study. BMJ 2010 Mar 18;340:c1279.

4. Li F, Chen G, Wang J, Liu H, Wu J. A case-control study on risk factors associated with death in pregnant women with severe pandemic H1N1 infection. BMJ Open 2012 Jul 7;2(4): $1-4$.

5. Goldkind SF, Sahin L, Gallauresi B. Enrolling pregnant women in research--lessons from the H1N1 influenza pandemic. N Engl J Med 2010 Jun 17;362(24):2241-3.

6. Akın L, Buzgan T, Bayazit Y, Buyurgan V, Tumay Ş. T.C. Sağlık Bakanlığı Temel Sağlık Hizmetleri Genel Müdürlüğü, Pandemik İnfluenza Ulusal Faaliyet Planı. Ankara: T.C Sağlık Bakanlığ1; Nisan 2006. http://www.grip.gov.tr/images/stories/ pdf/UPPTR.pdf

7. Influenza vaccination during pregnancy. Committee Opinion No. 468. Obstet Gynecol 2010 Oct;116(4):1006- 7.

8. Larson L, Mehta N, Paglia MJ, Bourjeily G, Ngan Kee WD. Pulmonary disease in pregnancy. In: Powrie RO, Greene MF, Camann W eds. De Swiet's Medical Disorders in Obstetric Practice. 5th Edition. MA, USA: Wiley-Blackwell; 2010: 1-47.

9. Freeman DW, Barno A. Deaths from Asian influenza associated with pregnancy. Am J Obstet Gynecol. 1959 Dec;78:1172-5.

10. Kumar A, Zarychanski R, Pinto R, Cook DJ, Marshall J, Lacroix J, et al. Critically ill patients with 2009 influenza A(H1N1) infection in Canada. JAMA. 2009 Nov 4;302(17): 1872-9.

11. Creanga AA, Johnson TF, Graitcer SB, Hartman L K, AlSamarrai T, Schwarz AG, et al. Severity of 2009 Pandemic Influenza A (H1N1) Virus infection in pregnant women. Obstet and Gynecol. 2010 Apr;115(4):717-26.

12. Jain S, Kamimoto L, Bramley AM, Schmitz AM, Benoit SR, Louie J, et al. Hospitalized patients with 2009 H1N1 influenza in the United States, April-June 2009. N Engl J Med. 2009 Nov 12;361(20):1935-44

13. Webb SA, Pettilä V, Seppelt I, Bellomo R, Bailey M, Cooper D J et al. Critical care services and 2009 H1N1 influenza in Australia and New Zealand. N Engl J Med. 2009 Nov 12; 361(20):1925-34. 
14. Karabulut A, Çalışkan A, Göncü F, Uyar S, Kutlu M. H1N1 infection in pregnancy: clinical course in two women. $J$ Turkish-German Gynecol Assoc 2011;12:118-20.

15. Siston AM, Rasmussen SA, Honein MA, et al. Pandemic 2009 influenza A (H1N1) virus illness among pregnant women in the United States. JAMA 2010 Apr 21;303(15):1517-25.

16. Louie JK, Acosta M, Jamieson DJ, Honein M. Severe 2009 $\mathrm{H} 1 \mathrm{~N} 1$ influenza in pregnant and postpartum women in California. N Engl J Med 2010 Jan 7;362(1):27-35.

17. Tanaka T, Nakajima K, Murashima A, Garcia-Bournissen F, Koren G, Ito S. Safety of neuraminidase inhibitors against novel influenza A (H1N1) in pregnant and breastfeeding women. CMAJ. 2009 Jul 7;181(1-2):55-8.

18. Meeting of the Strategic Advisory Group of Experts on immunization, April 2010- conclusions and recommendations. Wkly Epidemiol Rec. 2010 May 28;85(22):197-212.

19. Nordin JD, Kharbanda EO, Benitez GV, Nichol K, Lipkind H, Naleway A, et al. Safety of trivalent inactivated influenza vaccine in pregnant women. Obstet Gynecol 2013 Mar:121(3): 519-25.

20. Conlin AM, Bukowinski AT, Sevick CJ, DeScisciolo C, Crum- Cianflone NF. Safety of the pandemic H1N1 influenza vaccine among pregnant U.S. military women and their infants. Obstet Gynecol 2013 Mar;121(3):511-8. 